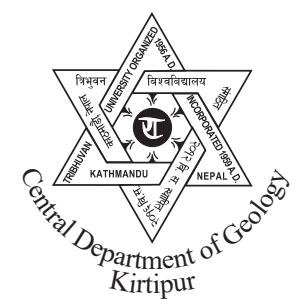

Bulletin of the Department of Geology

\title{
Evaluation of aggregates from conglomerate beds of the Upper Siwalik Subgroup, Chure Khola area, Central Nepal Sub-Himalaya
}

\author{
*Sunil Shanker Pradhananga and Naresh Kazi Tamrakar \\ Central Department of Geology, Tribhuvan University, Kathmandu, Nepal
}

\begin{abstract}
Durability of infrastructures demands detail study of rocks which helps to give knowledge on physical properties, strength and durability of rocks, and their usefulness as construction materials. A wide belt of conglomerates of the Upper Siwalik Subgroup (Pliocene to Lower Pleistocene) extends in the Chure Hills of Central Nepal. These conglomerates are mostly loosely consolidated, matrix-supported and containing clast of diverse composition. Because of haphazard mining of the riverbeds of the Chure and Dudhaura Kholas, the present study was carried out for evaluation of clasts from the conglomerates distributed at the hillslopes of the Chure Khola, as alternative sources mainly for unbound pavement. Stiffness and durability of clasts from conglomerates was tested for grading, shape indices, Water Absorption Value (WAV), specific gravity, Aggregate Impact Value (AIV), Aggregate Crushing Value (ACV), Los Angles Abrasion Value (LAV), Sodium Sulphate Soundness Value (SSSV) and Slake Durability Index (SDI). The suitability of clast from conglomerates for unbound pavement was finally evaluated for the sample for intended uses following specifications of British standard, ASTM standard and Nepal standard.

The clasts of conglomerate beds are composed of quartzite, sandstone, siltstone, schist, marble, phyllite, granite, limestone and amphibolite. Among all those clasts, quartzite is dominant in all samples. The texture of clast is smooth and rough surface. Flakiness index (FI) and Elongation index (EI) indicate that aggregates possess only some flat and elongate grains and are good in workability. WAV lies below $3 \%$ and the dry density $\left(2260 \mathrm{~kg} / \mathrm{m}^{3}-2750 \mathrm{~kg} / \mathrm{m}^{3}\right)$ of aggregates, coincides with the standard average value of ASTM Standard, British Standard and Nepal Standard. The ACV of the sample lies in the range $17 \%$ to $26 \%$ within the limit of ASTM standard, BS and Nepal Standard. The Los Angles Value of the sample lies in the range $34 \%$ to $44.60 \%$ and therefore, they can be used for base course and sub base course. SSSV for five cycles was calculated to be less than $10 \%$. SDI after second cycle is very high (94.29\%) and samples are durable in nature according to ASTM D464487 Standard. All parameters show that the sample of the clast of conglomerate deposited along the Chure Khola are durable meeting all ASTM, British and Nepal Standard and thus are suitable unbound pavement.
\end{abstract}

Key words: Texture, grain interlocking, micropetrographic index, index properties, construction material

Received: 20 June, 2016

Accepted: 22 July, 2016

\section{INTRODUCTION}

Conglomerates are widely distributed in the Chure Range, and can be good resource for unbound pavement base and sub base aggregates for road construction. The Chure Khola hillslope of the Upper Siwalik Subgroup in the Chure Hills of Nepal possesses two formations in small range and has got great potential of aggregates. Several quarry sites have been runing on the banks of the Chure Khola, which consists of large volume of the clasts probably suitable for aggregates. The riverbed

*Corresponding author:

E-mail address: mallasunil12@gmail.com materials deposited have been quarried in many places by locals for construction materials. The Chure Khola Hills are being eroded day by day and consequently sediments are being deposited excessively in the downstream portions. It is better to focus quarry in some localized sites to minimize impact due to river mining.

Bajarnason et al. (2000) studied the unbound aggregates in road construction and showed that for Icelandic basalt the durability test results and abrasion test results were dependent on the degree of alteration while the fragmentation test results were dependent on porosity. 
Tamrakar et al. (2002) concluded that dry density and porosity were correlated well with uniaxial compressive strength, point load index and modulus ratio of the Siwalik sandstones. Tamrakar et al. (2007) established relationship among physical, mechanical and petrographical properties of the Siwaliks sandstone, Hetauda-Amlekhganj area. Khanal and Tamarakar (2009) evaluated quality of crushed-limestone and siltstone for road aggregates. Gondal et al. (2009) evaluated engineering properties of these local aggregates for use in roads and concrete. Shrestha and Tamrakar (2013) suggested suitability of natural gravels from the Trishuli Ganga River for base and sub-base courses.

The present study aims to find the strength and durability of conglomerate clasts from the Siwalik Group, and to evaluate suitability of clasts from the conglomerates for unbound pavement.

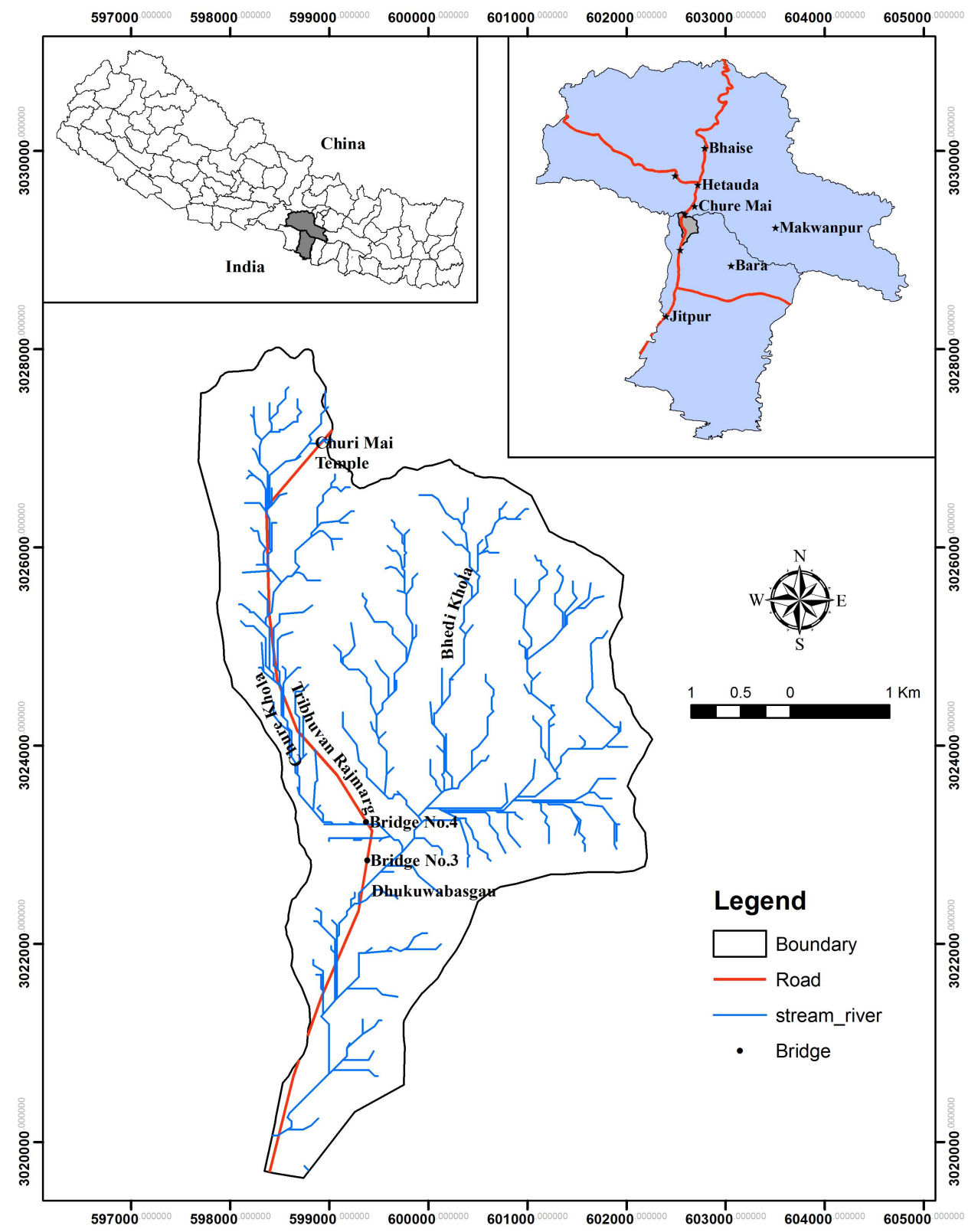

Fig. 1 Location map of the study area 


\section{METHODOLOGY}

The study area lies in the Bara District of the Narayani Zone. The study area covers the Chure Khola catchment area, but mainly focuses on the sub catchment of the Chure Khola and its tributaries from Bridge no 3 to Churia Mai Range (Fig. 1). The study area is mainly drained by the Chure Khola. The Bhedi Khola is the major tributary that joins in the Chure Khola and flows southwards.

A regional geological mapping of the Upper Siwalik Subgroup, along and around the Chure Khola subwatershed was carried out using topographic map $(1: 25000)$ scale. In the field recording of overburden thickness and sampling of conglomerate beds from various locations were made. The representative samples (weight 25 to $30 \mathrm{Kg}$ per station) from various lithological formations were collected systematically for the laboratory study.

The properties used to assess the suitability of clasts as aggregate materials included the following tests: Flakiness Index and Elongation Index, Water Absorption, Dry Density Tests, Aggregate Crushing value (ACV), Aggregate Impact Value (AIV), Los Angeles Abrasion value (LAAV), slake durability index and sodium sulphate soundness.

In the laboratory, Sieve analyses were conducted in accordance with ASTM C 136 for the coarse and fine fractions, and the data were used to plot 0.45 power chart and combined percent retained grain size chart.

The Elongation Index (EI) was calculate by using the equation after BS 812105.2 (1990). Similarly, Flakiness Index (FI) was calculated by using the equation after BS 812 105.1 (BS, 1989).

The physical properties such as water absorption and dry density, and specific gravity were determined after ASTM C 127 (2011). Samples were immersed in water for 24 hours, surface dried, weighed and percent absorption relative to dry weight were calculated as water absorption.

Specific gravity (SG) is a mass of a given substance divided by unit mass of an equal volume of water. Depending on the moisture condition, specific gravity can be oven dried, or saturated surface dry. Apparent specific gravity (ASG) is given by the ratio of density of the particles to the density of the water.

Los Angles Abrasion test were made following ASTM C131 to obtain mechanical soundness or hardness against abrasion of aggregate. The number of sphere charged were 12 . The initial weight used was 5 $\mathrm{kg}$. The number of revolution of the drum was 500 .

The slake durability test was made following IS 10050 to useful in determining the disintegration nature of the rocks when it is subjected to drying and wetting conditions along with movement. This test properly defines the weathering behavior of rocks and records the nature of the sample after the test (ASTM 4644-87).

To obtain soundness of aggregates against frosting and chemical weathering, sulphate soundness test was made based on ASTM C88-05 (ASTM, 2005, 2010). The sodium sulphate soundness value (SSV) in percentage was obtained as the relative loss of the fine $(<10 \mathrm{~mm})$ after five cycles of test. Sulphate soundness value greater than $10 \%$ indicates that the sample is chemically unsound ASTM C33 (ASTM, 1994).

\section{GEOLOGICAL SETTING}

The Amlekhgunj-Hetauda area lies within the SubHimalaya or Siwalik (Chure) Range of Nepal. On the basis of lithological characters, the Siwalik deposits in the Amlikhganj-Hetauda section have been divided in four lithostratigraphic units (Sah et al., 1994). They are Rapti, Amlekhganj, Chure Khola and Churia Mai Formations in ascending order.

The Chure basin extends from the ridge of the Churia Mai Range in the north to the alluvial fan deposit lying in the south, near the Amlekhganj Bazar. The Chure Khola Basin constitutes four different lithological units in addition to the Quaternary fan deposits (Fig. 2). These are the Upper Member of the Rapti Formation (Middle Siwalik Subgroup), Amlekhganj Formation (Middle Siwalik Subgroup), Chure Khola Formation (Upper Siwalik conglomerates), and the Churia Mai Formation (Upper Siwalik boulder beds). The main concern of the study of the Upper Siwalik Subgroup is the Chure Khola Formation (Upper Siwalik conglomerates including calcareous conglomerate beds) and the Churia Mai Formation (Upper Siwalik boulder beds). 


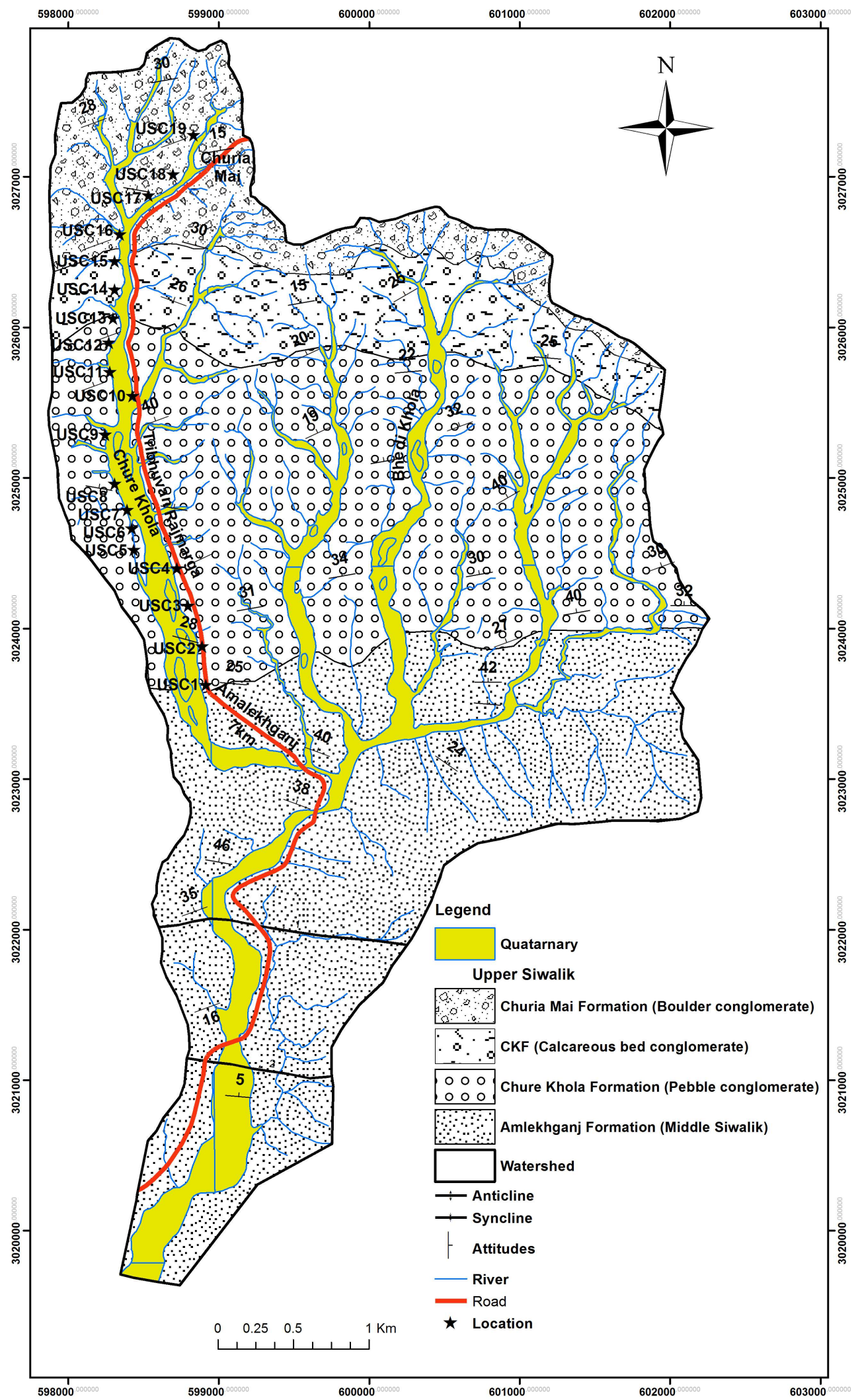

Fig. 1 Location map of the study area 


\section{Chure Khola Formation}

The Chure Khola Formation is formation is about $2000 \mathrm{~m}$ thick and consists predominantly of matrix- to clast-supported pebbly conglomerates with subordinate sandstone and mudstone beds. It is widely distributed along the Chure Khola, the Bhedi Khola and other tributaries areas .The formation is distinguished from the hogback topography of the Amlekhganj Formation by the low-angle dipping beds (20-35 degrees) characterized by irregular bad land topographic feature with several vertical fractures.

In the Chure Khola, at the lower part of the formation, it comprises massive, planar cross- bedded, pebbly, sandy, matrix-supported conglomerates interbedded with few layers of light yellow, bluish grey to light grey, reddish brown mudstone beds. Clasts in conglomerates are mainly composed of quartzite, granite, gneiss, sandstone and siltstone, slate and others. The size of the cobbles and pebbles is 50 to $70 \mathrm{~mm}$ and 2 to $30 \mathrm{~mm}$, respectively. The proportion of clast to matrix varies from $74 \% / 26 \%$.

At the middle part of the formation along the Chure Khola, it comprises graded, poorly sorted, clast dominated, pebble-cobble conglomerates. Clasts are mainly composed of amphibolite, quartzite, phyllite, sandstone, and schist. However, some layers with boulders of up to $0.3 \mathrm{~m}$ are found. Matrix is light yellow, and is sandy mud. It is slightly calcareous with few lenses of sandy layers. Matrix proportion is about $30 \%$. The conglomerate bed is $14 \mathrm{~m}$ high containing loosely consolidated matrix supported cobble pebble conglomerate. The clast size increases vertically upward.

At the upper part of the formation along the Chure Khola, conglomerates are poorly sorted, moderately clast-supported, pebble- cobble to boulder-cobble. Clast ranges from granular to boulder and is mostly of quartzite, gneiss, granite, marble, sandstone and siltstone. The size of the boulder is up to $350 \mathrm{~mm}$, whereas that of the cobbles and pebbles is 100 to 120 $\mathrm{mm}$ and 40 to $50 \mathrm{~mm}$, respectively. The matrix is light yellow to reddish brown and is notably calcareous. The proportion of clast to matrix varies from $72 \% / 28 \%$.

On moving up of the sequence, the size of the clast increases and the rare red mud beds were encountered indicating depositional gap and sub-aerial exposure of the flood banks. These successions are followed more upstream by calcareous cemented conglomerate. This unit bears calcareous clast as well as matrix. The proportion of clast to matrix varies from $72 \% / 22 \%$ and $5 \%$ cement. The conglomerate beds show planar crossbedding to massive bedding, and roughly fining up of boulder dominant layers to cobble-pebble dominant layers. These sequences were interpreted to be formed in gravelly braided river system.

The lower part of the Upper Siwalik Subgroup exposed at the Bhedi khola contain a $16 \mathrm{~m}$ thick conglomerate bed, is covered by vegetation in the upper portion but is exposed in the lower portion due to the river erosion. Thick bedded matrix supported pebble conglomerate, where the proportion of clast to matrix varies from $60 \% / 40 \%$. The size of the cobbles and pebbles is 80 to $90 \mathrm{~mm}$ and 30 to $40 \mathrm{~mm}$, respectively. Pebbles are mainly composed exclusively of subangular to sub-rounded pebbles derived from red-purple and brown as well as dark green, fine- to very finegrained, quartzose sandstone or quartzite. The transitional contact between the Middle and Upper Siwalik is observed about a few $100 \mathrm{~m}$ south of the Bhedi khola.

In the Bhedi khola, there are extremely thick $40 \mathrm{~m}$ high containing loosely consolidated matrix supported boulder cobble pebble conglomerate. The proportion of clast to matrix varies from $80 \% / 20 \%$. The size of the boulder is up to $200 \mathrm{~mm}$, whereas that of the cobbles and pebbles is 80 to $110 \mathrm{~mm}$ and 40 to $50 \mathrm{~mm}$, respectively. Boulders are mainly composed of quartzites.

In the Bhedi Khola, the exposure is extremely $40 \mathrm{~m}$ high and present of paleo red soil of thickness $0.5-1 \mathrm{~m}$. It consists of poorly consolidated calcareous matrix supported boulder cobble conglomerate. The proportion of clast to matrix varies from $75 \% / 22 \%$ and $3 \%$ cement of carbonate. Cobble is mainly composed of quartzites, sandstone, mudstone, schist and marble. The size of the boulder is up to $300 \mathrm{~mm}$, whereas that of the cobbles and pebbles is 200 to $250 \mathrm{~mm}$ and 100 to $150 \mathrm{~mm}$, respectively.

In other tributaries also the lower part of the Upper Siwalik cropping out parallel of the Bhedi Khola are 
composed of gray sandstone and dark gray mudstone interbeds. Thick bedded matrix supported cobble pebble conglomerate where the proportion of clast to matrix was $70 \% / 30 \%$.

In other tributaries at the middle part of the formation, the conglomerate beds $8 \mathrm{~m}$ high and $2.5 \mathrm{~m}$ terrace deposits. It consists of loosely consolidated matrix supported boulder cobble pebble conglomerate. The proportion of clast to matrix varies from $78 \% / 22 \%$. Boulder pebbles are mainly composed of quartzites. The general attitude of bed is $\mathrm{N} 65^{\circ} \mathrm{W} / 19^{\circ} \mathrm{NE}$.

\section{Churia Mai Formation}

The Churia Mai Formation is distributed around the Churia Mai Range, the catchments of the Chure Khola, Bhedi Khola and the other tributaries area, and is characterized by massive, poorly sorted, matrixsupported, and boulder-cobble conglomerate showing randomly oriented clastic fabric. Some pebble conglomerates are interbedded with minor sandstone and mudstone. Conglomerates frequently comprise clast of the Siwalik rocks, e.g., 'salt-and- pepper' sandstones. The formation is about $500 \mathrm{~m}$ thick, and covers about $4.6 \%$ area of the Chure Khola Basin.

In the Chure Khola, the lower part of the formation comprises highly calcareous and stiff, poorly graded and poorly sorted boulder cobble pebble conglomerates. The latter are very much calcareous due to abundant marble and sandstone boulders and sandy matrix. Clast of quartzite, shale, phyllite, gneiss and siltstone are also found. Few beds of grey mudstone are interbedded with conglomerates. The size of the boulder is up to $280 \mathrm{~mm}$, whereas that of the cobbles and pebbles is 100 to 240 $\mathrm{mm}$ and 40 to $60 \mathrm{~mm}$, respectively.

In the Bhedi Khola, the exposure is $12 \mathrm{~m}$ high and consists of poorly consolidated matrix supported Cobble conglomerate. The proportion of clast to matrix varies from $71 \% / 29 \%$. Attitude of bed is $\mathrm{N} 45^{\circ} \mathrm{W} / 35^{\circ} \mathrm{NE}$. Cobbles are mainly composed of quartzites, sandstone, mudstone, schist and phyllite.

The upper part of the formation comprises very gentle beds of matrix-supported and poorly sorted conglomerates interbedded with up to $5 \mathrm{~m}$ thick grey to yellow mudstones. Clasts of conglomerate are quartzite, granite, marble, and sandstone and siltstone of the
Lower Siwaliks. They are subrounded to sub angular. Matrix of sand is yellowish brown, and becomes more abundant compared to the conglomerate of the lower part. The proportion of clast to matrix from $73 \% / 27 \%$. The size of the boulder is up to $240 \mathrm{~mm}$, whereas that of the cobbles and pebbles is 100 to $180 \mathrm{~mm}$ and 30 to $70 \mathrm{~mm}$, respectively.

The Quatarnary Deposit of the river bed boulders and sand which lie along the East- West Highway. The clast are boulder, cobble, pebble or shingle sand, silt and clay according to their size limit in various deposits. The composition of clast consists of quartzite, sandstone, mudstone, limestone, marble, schist, granite, and amphibolite.

\section{RESULTS}

Nineteen samples were collected from nineteen sampling sites and innformation on the site is listed in Table 1. All the samples were collected from conglomerate beds of the Upper Siwalik Subgroup.

\section{Gradation}

The sieving was carried out in different sample locations while collecting the samples, therefore the data collected were according to the retained percentage. They were placed in a table and the graph plot was prepared to analyse the gradation of the aggregate.

On the basis of power curve (Fig. 3) there are six possible gradations among which most of sample point lies in gap-gradation (USC2, USC3, USC4, USC5,

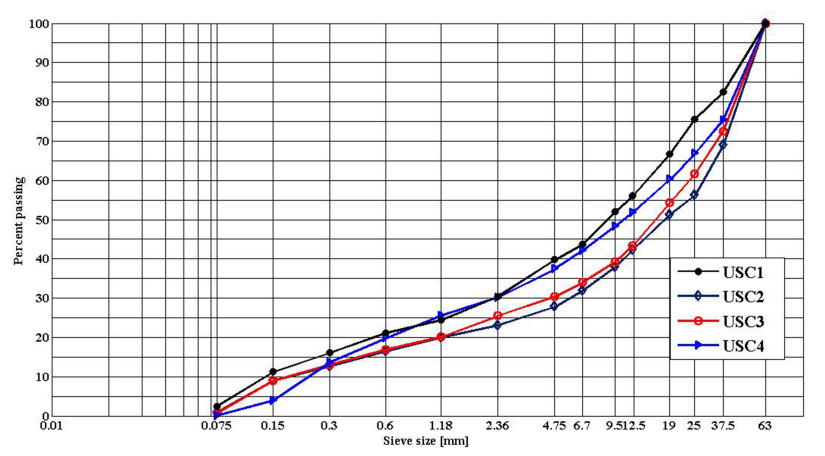

Fig. 3 Grain Size Distribution Curve of USC1, USC2, USC3 and USC4 
Table 1: Sampling location and samples

\begin{tabular}{|c|c|c|c|c|c|c|c|c|c|c|}
\hline Unit & $\begin{array}{l}\text { Sample } \\
\text { no. }\end{array}$ & Northing & Easting & Location & $\begin{array}{c}\text { Modal } \\
\text { size } \\
(\mathrm{mm})\end{array}$ & $\begin{array}{c}\text { Max } \\
\text { Size } \\
(\mathrm{mm})\end{array}$ & Sorting & $\begin{array}{c}\% \\
\text { Clast }\end{array}$ & $\begin{array}{c}\% \\
\text { Matrix }\end{array}$ & Lithology \\
\hline \multirow{14}{*}{ 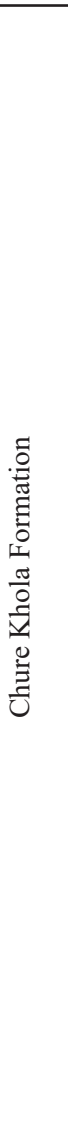 } & $\overline{\mathrm{USC} 1}$ & 3023625.86 & 598908.07 & $\begin{array}{l}\text { left bank of the } \\
\text { Chure Khola }\end{array}$ & 70 & 190 & Poor & 74 & 26 & $\begin{array}{l}\text { Matrix-supported, consolidation } \\
\text { loosely packed pebbly cgl }\end{array}$ \\
\hline & USC2 & 3023890.02 & 598883.61 & $\begin{array}{l}\text { left bank of the } \\
\text { Chure Khola }\end{array}$ & 70 & 150 & Poor & 78 & 22 & $\begin{array}{l}\text { Matrix-supported loosely } \\
\text { consolidated pebble cgl }\end{array}$ \\
\hline & USC3 & 3024149.30 & 598795.04 & $\begin{array}{l}\text { left bank of the } \\
\text { Chure Khola }\end{array}$ & 60 & 240 & Poor & 60 & 40 & $\begin{array}{l}\text { matrix-suppported, loosely } \\
\text { consolidated, pebble cgl }\end{array}$ \\
\hline & USC4 & 3024393.90 & 598717.28 & $\begin{array}{l}\text { left bank of the } \\
\text { Chure Khola }\end{array}$ & 70 & 180 & Poor & 70 & 30 & $\begin{array}{l}\text { Loosely consolidated, stratified, } \\
\text { pebble conglomerate with sand }\end{array}$ \\
\hline & USC5 & 3024521.10 & 598433.54 & $\begin{array}{l}\text { right bank of } \\
\text { the Chure Khola }\end{array}$ & 55 & 120 & Poor & 78 & 22 & $\begin{array}{l}\text { Matrix-supported, loosely } \\
\text { consolidated, graded cobble cgl }\end{array}$ \\
\hline & USC6 & 3024672.75 & 598423.76 & $\begin{array}{l}\text { right bank of } \\
\text { the Chure Khola }\end{array}$ & 70 & 190 & Poor & 74 & 26 & $\begin{array}{l}\text { Matrix-supported, loosely } \\
\text { consolidated, cobble pebble cgl }\end{array}$ \\
\hline & USC8 & 3024956.49 & 598321.02 & $\begin{array}{l}\text { right bank of } \\
\text { the Chure Khola }\end{array}$ & 50 & 150 & Poor & 75 & 25 & $\begin{array}{l}\text { Matrix-supported, loosely } \\
\text { consolidated, cobble pebble cgl }\end{array}$ \\
\hline & USC9 & 3025284.25 & 598242.75 & $\begin{array}{l}\text { right bank of } \\
\text { the Chure Khola }\end{array}$ & 60 & 240 & Poor & 80 & 20 & $\begin{array}{l}\text { Matrix-supported, loosely } \\
\text { consolidated, cobble pebble cgl }\end{array}$ \\
\hline & USC10 & 3025553.32 & 598428.65 & $\begin{array}{l}\text { left bank of the } \\
\text { Chure Khola }\end{array}$ & 70 & 180 & Poor & 78 & 22 & $\begin{array}{l}\text { Matrix-supported, loosely } \\
\text { consolidated, cobble pebble cgl }\end{array}$ \\
\hline & USC11 & 3025695.19 & 598277.00 & $\begin{array}{l}\text { right bank of } \\
\text { the Chure Khola }\end{array}$ & $7 \mathrm{~cm}$ & $13 \mathrm{~cm}$ & Poor & 72 & 28 & $\begin{array}{l}\text { Matrix-supported, loosely } \\
\text { consolidated, cobble pebble cgl }\end{array}$ \\
\hline & USC12 & 3025885.98 & 598267.21 & $\begin{array}{l}\text { right bank of } \\
\text { the Chure Khola }\end{array}$ & 70 & 190 & Poor & 75 & 25 & $\begin{array}{l}\text { Matrix-supported, loosely } \\
\text { consolidated, cobble pebble cgl }\end{array}$ \\
\hline & USC13 & 3026057.20 & 598301.46 & $\begin{array}{l}\text { right bank of } \\
\text { the Chure Khola }\end{array}$ & 50 & 150 & Poor & 72 & 28 & $\begin{array}{l}\text { Matrix-supported, calcarious } \\
\text { cobble pebble cgl }\end{array}$ \\
\hline & USC14 & 3026243.09 & 598306.35 & $\begin{array}{l}\text { right bank of } \\
\text { the Chure Khola }\end{array}$ & 60 & 240 & Poor & 78 & 22 & Boulder cobble cgl \\
\hline & USC15 & 3026438.78 & 598306.35 & $\begin{array}{l}\text { right bank of } \\
\text { the Chure Khola }\end{array}$ & 70 & 180 & Poor & 71 & 29 & $\begin{array}{l}\text { Cobble conglomerate, calcarious } \\
\text { matrix supported cgl }\end{array}$ \\
\hline \multirow{4}{*}{ 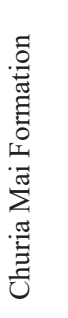 } & USC16 & 3026619.78 & 598350.38 & $\begin{array}{l}\text { right bank of } \\
\text { the Chure Khola }\end{array}$ & 70 & 190 & Poor & 73 & 27 & Matrix-supported, cobble cgl \\
\hline & USC17 & 3026883.95 & 598521.60 & $\begin{array}{l}\text { right bank of } \\
\text { the Chure Khola }\end{array}$ & 50 & 150 & Poor & 72 & 28 & Matrix-supported, cobble cgl \\
\hline & USC18 & 3027020.93 & 598692.82 & $\begin{array}{l}\text { right bank of } \\
\text { the Chure Khola }\end{array}$ & 60 & 240 & Poor & 80 & 20 & $\begin{array}{l}\text { Matrix-supported, loosely } \\
\text { consolidated, boulder cobble cgl }\end{array}$ \\
\hline & USC19 & 3027285.10 & 598829.80 & $\begin{array}{l}\text { right bank of } \\
\text { the Chure Khola }\end{array}$ & 70 & 180 & Poor & 73 & 27 & $\begin{array}{l}\text { Matrix-supported, loosely } \\
\text { consolidated, boulder cgl }\end{array}$ \\
\hline
\end{tabular}

USC6, USC10, USC11, USC16, USC17, USC18, and USC19). Remaining samples from sample points USC 8, USC9, USC12 and USC13 are coarse gradation and USC 1 is fine graded.

\section{Shape Indices}

Shape indices are attributed by an elongation index and a flakiness index. The results of shape indices measurements are listed in Table 2. The samples obtained from various sample points gives flakiness index of $13.46 \%-34.63 \%$, among which USC1, USC2, USC3, USC5, USC6, USC9, USC10, USC11, USC16, and USC18 are suitable for concrete mix according to BS812 Part 105.1 limit of $<25 \%$. The flakiness index of USC4, USC8, USC12, USC13, USC17 and USC19 exceeds the specified limit of 25\% (BS812 Part 105.1), whereas the elongation index of all the samples except USC3 and USC16 exceed the limit $(<25 \%)$ of BS812 Part 105.2. 
Table 2: Shape indices of aggregates

\begin{tabular}{|ccccc}
\hline Sample No. & $\begin{array}{c}\text { Flakiness } \\
\text { Index, } \%\end{array}$ & $\begin{array}{c}\text { Elongation } \\
\text { Index, } \%\end{array}$ & Smooth, \% & Rough, $\%$ \\
\hline USC1 & $13.46 \%$ & $17.84 \%$ & 73.21 & 26.79 \\
USC2 & $14.94 \%$ & $24.51 \%$ & 77.97 & 22.03 \\
USC3 & $22.02 \%$ & $30.22 \%$ & 73.68 & 26.32 \\
USC4 & $26.19 \%$ & $12.77 \%$ & 92.41 & 7.59 \\
USC5 & $19.77 \%$ & $22.62 \%$ & 94.12 & 5.88 \\
USC6 & $14.48 \%$ & $20.28 \%$ & 82.00 & 18.00 \\
USC8 & $31.70 \%$ & $21.72 \%$ & 87.93 & 12.07 \\
USC9 & $19.20 \%$ & $19.80 \%$ & 50.79 & 49.21 \\
USC10 & $21.56 \%$ & $15.25 \%$ & 74.19 & 25.81 \\
USC11 & $22.14 \%$ & $16.56 \%$ & 62.3 & 37.7 \\
USC12 & $27.09 \%$ & $22.61 \%$ & 75.41 & 24.59 \\
USC13 & $25.13 \%$ & $20.10 \%$ & 61.97 & 38.03 \\
USC16 & $21.21 \%$ & $33.84 \%$ & 83.33 & 16.67 \\
USC17 & $28.95 \%$ & $21.43 \%$ & 80.00 & 20.00 \\
USC18 & $22.06 \%$ & $19.98 \%$ & 81.67 & 18.33 \\
USC19 & $34.63 \%$ & $19.66 \%$ & 83.33 & 16.67 \\
\hline
\end{tabular}

\section{Composition}

All the conglomerate samples were washed using water to remove surface coating of organic material and clay. Hand specimen identification of $37.5 \mathrm{~mm}, 25 \mathrm{~mm}$, $19 \mathrm{~mm}, 12.5 \mathrm{~mm}, 9.5 \mathrm{~mm}, 6.7 \mathrm{~mm}$ sieve sizes retained of the conglomerates composition in the laboratory were done to obtain composition of the conglomerates of each sample. The major compositions of the Chure River are quartzite, sandstone, mudstone, schist, phyllite, metasandstone, granite, amphibolite limestone and marble. Among them quartzite is dominant in all samples. The maximum and minimum percentages of quartzite present in the Chure Khola samples are USC18 (96\%) and USC17 (58\%), respectively (Table 3 ). The conglomerates of sandstone, mudstone, schist, granite and phyllite are low in percentage in all samples. The maximum percentage of marble in the USC13 is 35.

\section{Specific Gravity and Water Absorption}

The average dry density and water absorption of each sample were calculated for aggregate of different sample pointss of conglomerate bed of the Chure Khola. The relative densities range from 2.44 to 2.84 . Based on relative densities of aggregates according to ASTM C 128, the tested samples fall on heavy weight aggregates and are greater than 2.6 to meet the standard. The water absorption value (WAV) ranges from $1.01 \%$

Table 3: Composition of aggregates

\begin{tabular}{|c|c|c|c|c|c|c|c|c|c|c|}
\hline \multirow{2}{*}{$\begin{array}{c}\text { Sample } \\
\text { No. }\end{array}$} & \multicolumn{9}{|c|}{ Composition percentage } & \multirow[b]{2}{*}{ Total } \\
\hline & Quartzite & Sandstone & Siltstone & Schist & Marble & Phyllite & Granite & Limestone & Amphibolite & \\
\hline USC1 & 86 & 7 & 1 & 6 & 0 & 0 & 0 & 0 & 0 & 100 \\
\hline USC2 & 89 & 5 & 2 & 1 & 0 & 0 & 0 & 1 & 2 & 100 \\
\hline USC3 & 83 & 11 & 3 & 2 & 0 & 1 & 0 & 0 & 0 & 100 \\
\hline USC4 & 90 & 4 & 1 & 2 & 0 & 0 & 0 & 0 & 3 & 100 \\
\hline USC5 & 91 & 4 & 0 & 4 & 0 & 1 & 0 & 0 & 0 & 100 \\
\hline USC6 & 87 & 8 & 3 & 2 & 0 & 0 & 0 & 0 & 0 & 100 \\
\hline USC8 & 84 & 9 & 3 & 1 & 0 & 0 & 0 & 0 & 2 & 100 \\
\hline USC9 & 84 & 9 & 3 & 1 & 0 & 0 & 0 & 0 & 2 & 100 \\
\hline USC 10 & 72 & 14 & 2 & 10 & 0 & 0 & 1 & 0 & 0 & 100 \\
\hline USC11 & 87 & 10 & 0 & 2 & 0 & 1 & 0 & 0 & 0 & 100 \\
\hline USC12 & 89 & 7 & 0 & 3 & 0 & 2 & 0 & 0 & 0 & 100 \\
\hline USC13 & 54 & 6 & 1 & 2 & 36 & 1 & 0 & 0 & 0 & 100 \\
\hline USC16 & 70 & 7 & 2 & 5 & 1 & 0 & 7 & 0 & 8 & 100 \\
\hline USC17 & 59 & 22 & 4 & 11 & 0 & 4 & 0 & 0 & 0 & 100 \\
\hline USC 18 & 93 & 4 & 1 & 1 & 0 & 0 & 0 & 0 & 2 & 100 \\
\hline USC19 & 88 & 9 & 2 & 0 & 2 & 0 & 0 & 0 & 0 & 100 \\
\hline
\end{tabular}


Table 4: Specific gravity and water absorption value

\begin{tabular}{cccccccc}
\hline $\begin{array}{c}\text { Sample } \\
\text { No. }\end{array}$ & $\begin{array}{c}\text { Oven-dry } \\
\text { Weight, } \\
(\mathrm{gm}), \mathrm{A}\end{array}$ & $\begin{array}{c}\text { Saturated } \\
\text { surface-dry } \\
\text { weight }(\mathrm{gm}), \mathrm{B}\end{array}$ & $\begin{array}{c}\text { Wt. of Saturated } \\
\text { sample immersed in } \\
\text { water (gm), C }\end{array}$ & $\begin{array}{c}\text { SSD bulk } \\
\mathrm{G}\end{array}$ & $\begin{array}{c}\text { Water } \\
\text { absorption } \\
\text { Value }(\%)\end{array}$ & $\begin{array}{c}\text { Dry Bulk } \\
\text { Density } \\
\left(\mathrm{kg} / \mathrm{m}^{3}\right)\end{array}$ & $\begin{array}{c}\text { Apparent } \\
\text { relative } \\
\text { Density }\end{array}$ \\
\hline USC1 & 980 & 1000 & 620 & 2.63 & 2.04 & 2580 & 2.72 \\
USC2 & 970 & 990 & 590 & 2.48 & 2.06 & 2430 & 2.55 \\
USC3 & 980 & 1000 & 620 & 2.63 & 2.04 & 2580 & 2.72 \\
USC4 & 950 & 980 & 560 & 2.33 & 3.16 & 2260 & 2.44 \\
USC5 & 980 & 1000 & 570 & 2.33 & 2.04 & 2280 & 2.39 \\
USC6 & 970 & 980 & 600 & 2.58 & 1.03 & 2550 & 2.62 \\
USC8 & 970 & 1000 & 620 & 2.63 & 3.09 & 2550 & 2.77 \\
USC9 & 960 & 980 & 610 & 2.65 & 2.08 & 2590 & 2.74 \\
USC10 & 950 & 970 & 610 & 2.69 & 2.11 & 2640 & 2.79 \\
USC11 & 980 & 990 & 610 & 2.61 & 1.02 & 2580 & 2.65 \\
USC12 & 990 & 1000 & 625 & 2.67 & 1.01 & 2640 & 2.71 \\
USC13 & 980 & 1000 & 595 & 2.47 & 2.04 & 2420 & 2.55 \\
USC16 & 970 & 1000 & 614 & 2.59 & 3.09 & 2510 & 2.72 \\
USC17 & 950 & 960 & 615 & 2.78 & 1.05 & 2750 & 2.84 \\
USC18 & 980 & 1000 & 625 & 2.67 & 2.04 & 2610 & 2.76 \\
USC19 & 950 & 965 & 610 & 2.72 & 1.58 & 2680 & 2.79 \\
\hline
\end{tabular}

to $3.16 \%$. The WAV of the samples are less than $3 \%$, which indicates very low effective porosity, and are within the specification of ASTM C 128. When WAV is low the access of reactants to inside of aggregate to attack becomes low, and therefore aggregates will be strong enough to withstand chemical reaction against cement and weathering fluids. The particle having high porosity is easily and rapidly attacked by chemical as a result it will expand and cracks will develop. Water absorption value is also relates closely some other undesirable properties such as poor resistance to frost action or other weathering agencies.

Dry density of aggregates used in construction is $2000-3000 \mathrm{~kg} / \mathrm{m}^{3}$ and average value is about 2600 $\mathrm{kg} / \mathrm{m}^{3}$ used in road construction (ASTM 1994). The dry density of USC4 is the lowest i.e. $2260 \mathrm{~kg} / \mathrm{m}^{3}$ and highest is of USC17 i.e. $2750 \mathrm{~kg} / \mathrm{m}^{3}$. The result shows that samples have low effective porosity.

Generally, specific gravity between 2 to 3 is suitable to use in construction materials (BS). Specific gravity of samples is found to range between 2.33 (USC4 and USC5) and 2.78 (USC17).

\section{Aggregate Crushing Value (ACV)}

The aggregate crushing value indicates the ability of an aggregate to resist crushing. Lower the value, stronger the aggregate, i.e. greater its ability to resist crushing. The calculated ACV ranges from $17.43 \%$ to $25.67 \%$. The ACV up to $30 \%$ is mechanically sound for road aggregate (DOR, 2015). The aggregate samples are stronger and mechanically sound. The ACV of USC17 is maximum because it possesses dry density of $2.75 \mathrm{~kg} / \mathrm{m}^{3}$ which the highest dry bulk density among all sample point.

\section{Aggregate Impact Value (AIV)}

The result of aggregate impact test value ranges from $14 \%$ to $32.60 \%$. The AIV lying between $10-20 \%$ is strong. The AIV between $20-30 \%$ is satisfactory. Therefore, according ASTM, 1979, the values agree with the standard values and indicate that some clasts are strong (USC4, USC8, USC9, USC11, USC12, USC13 and USC18) and some are satisfactory (USC1, USC5, USC6, USC10, USC16 and USC19 to resist impact. The entire samples are appropriate to use in 
Table 5: ACV, AIV, Los Angeles Abrasion value and slake durability index of the aggregates tested

\begin{tabular}{lccccc}
\hline Sample no. & ACV (\%) & *AIV \% & $\begin{array}{c}\text { Los Angles } \\
\text { Abrasion Value, } \%\end{array}$ & Moisture Content (\%) & $\begin{array}{c}\text { Slake Durability Index } \\
\text { (Second cycle) }(\%)\end{array}$ \\
\hline USC1 & 22.7 & 21.0 & 41.4 & 0.18 & 99.56 \\
USC2 & 25.5 & 32.6 & 53.0 & 0.13 & 99.09 \\
USC3 & 25.7 & 31.4 & 49.0 & 0.02 & 96.99 \\
USC4 & 21.8 & 19.6 & 37.2 & 0.11 & 98.15 \\
USC5 & 20.7 & 22.0 & 36.6 & 0.06 & 95.66 \\
USC6 & 19.5 & 24.2 & 37.0 & 2.46 & 99.3 \\
USC8 & 22.0 & 15.2 & 38.0 & 2.5 & 94.62 \\
USC9 & 19.7 & 14.2 & 38.2 & 2.5 & 97.69 \\
USC10 & 17.4 & 20.6 & 41.0 & 2.6 & 98.43 \\
USC11 & 18.9 & 15.0 & 35.0 & 2.48 & 99.43 \\
USC12 & 21.3 & 17.0 & 34.0 & 2.56 & 99.18 \\
USC13 & 20.0 & 17.2 & 38.2 & 0.29 & 98.55 \\
USC16 & 22.8 & 28.4 & 44.6 & 0.16 & 89.02 \\
USC17 & 25.7 & 32.2 & 52.0 & 0.24 & 90.66 \\
USC18 & 21.2 & 14.0 & 36.8 & 0.07 & 99.58 \\
USC19 & 21.0 & 20.6 & 36.4 & 0.1 & 92.27 \\
\hline
\end{tabular}

*AIV (ASTM, 1979): < $10 \%$ exceptionally strong; $10-20 \%$ strong; $20-30 \%$ satisfactory for pavement surfacing; $>35 \%$ weak for pavement; ** Los Angeles Value (\%) (Wr500) (ASTM, 1979): <16 coment concrete; <30 bituminous mix surface; $<50$ base course for road; Los Angeles Value (\%) (Wr500) (BS812, 882): $<40$ wearing course; $<50$ base course; + Slake Durability Index (ASTM Method D 4644-87): 0-25 very low; $>25$ to 50 low; $>50$ to 75 medium; $>75$ to 90 high; $>90$ to 95 very high; $>95$ to 100 extremely high.

aggregate. USC2 and USC17 are not suitable for pavement construction.

\section{Los Angeles Abrasion Value (LAAV)}

The value that is obtained from each sample is shown in Table 5 where each sample was done one time testing to obtain the abrasion value. The samples from 16 different locations were prepared in order to carry out Los Angeles abrasion test. The Los Angles Abrasion values of the samples ranges from $34 \%$ to $53 \%$ (table 5). With reference to ASTM, 1979 shows whole samples except two (USC2 and USC17) are appropriate for base course for road and and for base course $(<50 \%)$ (USC 1, USC3, USC4, USC5, USC6, USC8, USC9, USC10, USC11, USC12, USC13, USC16, USC 18 and USC19). Therefore lower LA abrasion loss values indicate aggregate that is tougher and more resistant to abrasion. The LAAV is high in USC2 and USC17 as,
$53 \%$ and $52 \%$ respectively, which intimation not resistant to abrasion; these sample points possess soft rock as Limestone, schist mudstone and sandstone in remarkable amount.

\section{Slake Durability Test}

The slake durability test was carried out with 16 samples. Thus, the various percentage of retention of the samples was found out. It was seen that the sample percentage retention after the second cycle of the slake durability test it was found that the sample retention percentages ranged from $89.02 \%$ to $99.56 \%$ (Table 5).

Hence, taking the average of the retention percentages after the first cycle and the second cycle, the value of retention after the value after second cycle was found to be $94.29 \%$ (Table 5). Therefore, comparing the average values found with the IS 100501981 table of classification, the samples were found to 

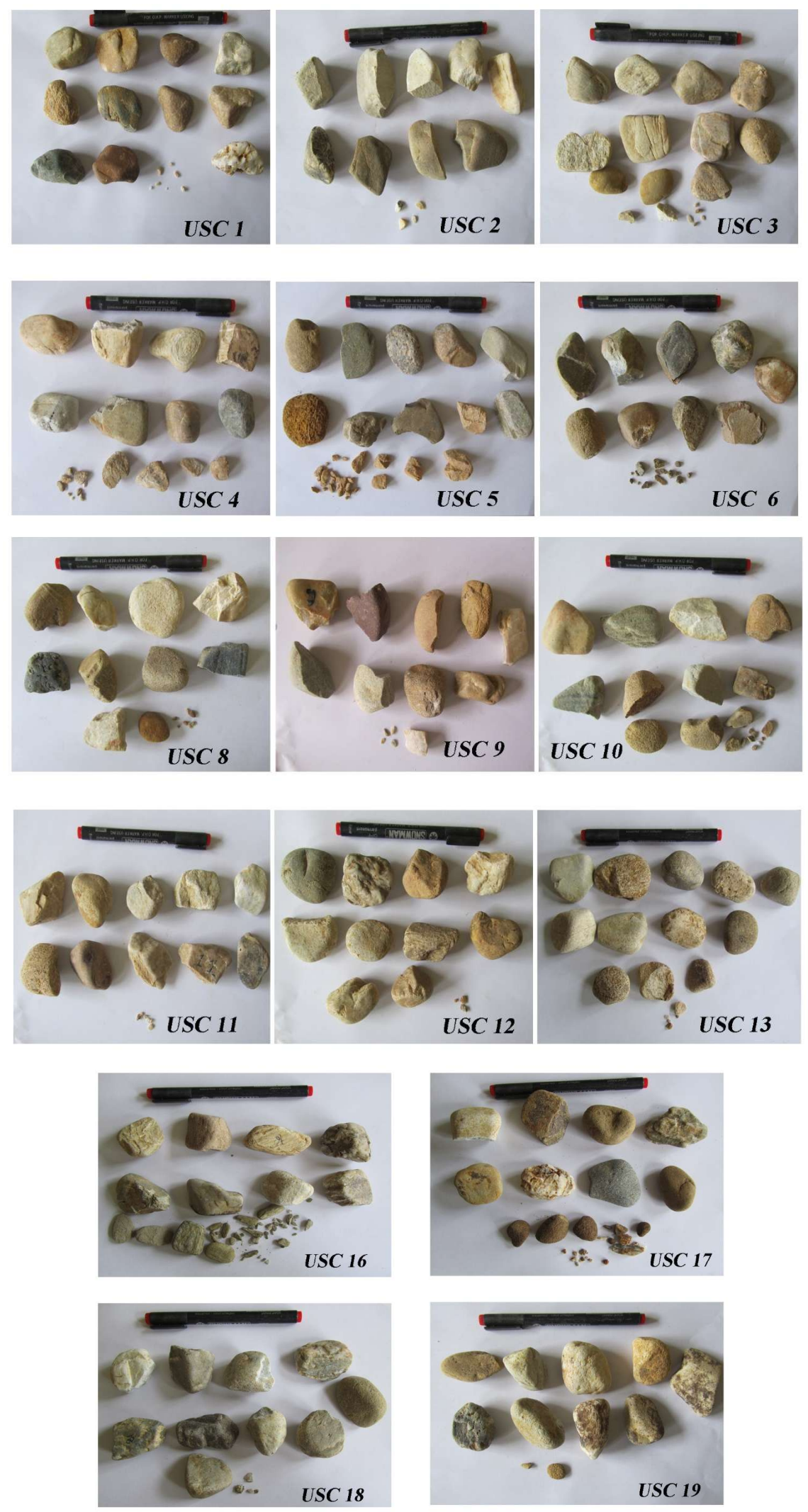

Fig. 4 Samples showing type I category after the slake durability test 
Table 6: Sodium sulphate soundness value (SSSV) of the aggregates tested

\begin{tabular}{lcccccccc}
\hline & & \multicolumn{7}{c}{ Weight (gm) } \\
\cline { 3 - 6 } Location & $\begin{array}{c}\text { Initial } \\
\text { wt. }\end{array}$ & $\begin{array}{c}\text { After 1st } \\
\text { cycle }\end{array}$ & $\begin{array}{c}\text { After 2nd } \\
\text { cycle }\end{array}$ & $\begin{array}{c}\text { After 3rd } \\
\text { cycle }\end{array}$ & $\begin{array}{c}\text { After 4th } \\
\text { cycle }\end{array}$ & $\begin{array}{c}\text { After 5th } \\
\text { cycle }\end{array}$ & $\begin{array}{c}\text { SSSV } \\
(\%)\end{array}$ & $\begin{array}{c}\text { Ratio between 1st and } \\
\text { Last wt. loss }\end{array}$ \\
\hline USC1 & 670 & 668.00 & 667.00 & 661.80 & 659.10 & 653.00 & 2.54 & 0.32 \\
USC2 & 670 & 664.32 & 658.33 & 650.81 & 646.96 & 641.58 & 4.24 & 1.02 \\
USC3 & 670 & 664.72 & 656.80 & 650.41 & 638.53 & 627.97 & 6.27 & 0.48 \\
USC4 & 670 & 669.00 & 656.50 & 654.30 & 641.00 & 634.40 & 5.31 & 0.14 \\
USC5 & 670 & 668.80 & 655.80 & 648.00 & 639.00 & 631.00 & 5.82 & 0.14 \\
USC6 & 670 & 669.07 & 645.60 & 637.36 & 627.58 & 624.49 & 6.79 & 0.28 \\
USC8 & 670 & 667.48 & 658.73 & 654.70 & 654.20 & 653.19 & 2.51 & 2.44 \\
USC9 & 670 & 668.78 & 661.97 & 657.09 & 646.42 & 645.91 & 3.6 & 2.32 \\
USC10 & 670 & 667.71 & 658.35 & 646.91 & 640.15 & 638.38 & 4.72 & 1.24 \\
USC11 & 670 & 668.78 & 668.48 & 668.27 & 667.77 & 666.04 & 0.59 & 0.7 \\
USC12 & 670 & 668.49 & 655.91 & 651.88 & 637.78 & 635.77 & 5.11 & 0.71 \\
USC13 & 670 & 667.94 & 653.28 & 648.84 & 631.80 & 614.98 & 8.21 & 0.12 \\
USC16 & 670 & 666.70 & 660.17 & 656.00 & 645.31 & 633.95 & 5.38 & 0.28 \\
USC17 & 670 & 667.34 & 637.38 & 623.85 & 598.88 & 576.92 & 13.89 & 0.11 \\
USC18 & 670 & 668.16 & 659.26 & 653.63 & 637.27 & 633.89 & 5.39 & 0.52 \\
USC19 & 670 & 669.17 & 657.41 & 654.81 & 632.97 & 618.41 & 7.7 & 0.05 \\
\hline & & & & & & & &
\end{tabular}

be very high durable in nature. The samples obtain (Fig. 4) resemble Type I of ASTM Method D 4644-87 (ASTM, 2001) as retained pieces remain virtually unchanged.

\section{Sodium Sulphate Soundness Value (SSSV)}

Soundness test determines the resistance to disintegration of aggregates due to alternate cycles of dry and wet condition. The result of test samples varies from $0.59 \%$ to $13.89 \%$ (Table 6 ). The value below $12 \%$ is chemically sound (DOR, 2001 and NS: 297-1994) and above $10 \%$ is chemically unsound (ASTM C33, 1994). Except USC17, all other samples are durable and sound. The ratio of weight loss in first cycle to last cycle (Table 6) shows that the samples USC2, USC8, USC9 and USC10 suffer large initial weight loss and progressively low weight loss in subsequent stages, probably suggesting removing of outer altered rims from the clasts..

\section{Evaluation of Clasts from the Conglomerate for Unbound Pavement}

The samples USC2, USC3 and USC17 are not so appropriate to use in unbound pavement as in Table 7 because its AIV and LAAV are high. USC17 has high SSSV and clay matrix is present, therefore, it is chemically and mechanically unsound. The water absorption value and dry density are average and meet the existing standard value for unbound pavement in all samples except USC4, USC 8 and USC16 according to ASTM. Slake durability test is above $60 \%$ indicating durable rock-like (ASTM D4644-08). Alkali-silica reactive parameters are low in all samples expect USC17 and the presence of deleterious materials like clay and mica in almost all samples is little and other harmful swelling clay minerals are absent.

LAAV and AIV showed the sample to be suitable for sub base and base course of III and IV and I and II apart from sample of USC2, USC3 and USC 17, which have exited value according to DOR (2015). USC8, USC16 and USC19 have $>50$ elongation index representing 
Table 7: Classes of material Quality according to DOR (2015)

\begin{tabular}{cccccc}
\hline $\begin{array}{l}\text { Material } \\
\text { class }\end{array}$ & LAAV \% & AIV, ACV \% & SSSV \% & $\begin{array}{c}\text { Flakiness } \\
\text { Index \% }\end{array}$ \\
\hline A & & $<25$ & $<20$ & $<12$ & $<20$ \\
B & & $<30$ & $<20$ & $<12$ & $<25$ \\
C & C1 & $<35$ & $<25$ & $<12$ & $<25$ \\
& C2 & $<30$ & $<20$ & $<12$ & $<25$ \\
D & D1 & $<40$ & $<30$ & $<12$ & $<30$ \\
& D2 & $<35$ & $<20$ & $<12$ & $<30$ \\
E & E1 & $>35$ and $<50$ & $<25$ & $<18$ & - \\
& E2 & $>40$ and $<50$ & $<30$ & $<18$ & - \\
& E3 & $>50$ & $<30$ & $<18$ & - \\
\hline
\end{tabular}

these sample to be inappropriate for unbound pavement but their LAAV and AIV are suitable for the same. Thus, the elongation index should be reduced pephaps by blending before using these samples for base and sub base for unbound pavement.

\section{DISCUSSIONS}

The Upper Siwalik is divided into two formations i.e. the Chure Khola Formation and the Churia Mai Formation. The Chure Khola Formation, at the lower part of the formation, it comprises massive, planar cross-bedded, pebbly, sandy, matrix- supported conglomerates interbedded with few layers of light yellow, bluish grey to light grey, reddish brown mudstone beds. At the middle part of the formation, it comprises graded, poorly sorted, clast dominated, pebble-cobble conglomerates. Finally, at the upper part of the formation, conglomerates are poorly sorted, moderately clast-supported, pebble- cobble to bouldercobble.

The sample USC2, USC3 and USC17 is not appropriate to use in both concrete aggregate and unbound pavement because it is mechanically and chemically unsound. The other samples meet the existing standard value for unbound pavement as base and sub base. The WAV and dry density are below 3\% and $2000 \mathrm{~kg} / \mathrm{m} 3-3000 \mathrm{~kg} / \mathrm{m} 3$ for aggregate. The concrete aggregate exists in the flakiness index (13$35 \%)$ according to BS $(<50 \%)$. The combined FI and EI as limits of $50 \%$ as IS and $35 \%$ BS for unbound pavement, thus it should be reduced before using for base and sub base for unbound pavement. . The ACV and AIV are $17-23 \%$ and $14-28 \%$ which are below $30 \%$, show strong and satisfactory to resistance to impact load for concrete aggregate and unbound pavement as base course and sub base course need AIV 25\% and 30\% respectively. The LAAV is $34-49 \%$, which is under limit for base pavement ( $<50 \%$ ASTM, 1979). And unbound pavement, the limit base course and sub base should be as $35 \%$ and $45 \%$ respectively according to DOR (2015). The SSSV is $0.59-8.21 \%$, which resist to chemical weathering for unbound pavement. Therefore the unbound pavement can be used as base and sub base course, according to desire limit value (Table 1), following their grading, as requirement of this specification needs it.

\section{CONCLUSION}

1. The conglomerates of the Upper Siwalik Subgroup in the Chure Khola area vary from cobble pebble or pebble conglomerate in the southern portion to boulder conglomerate in the northern portion.

2. The clasts of conglomerate of the Chure Khola area are composed dominantly of quartzite, and are suitable for road construction, however because of the gap grading and excess coarse fractions, crushing of large particles and then blending will be required.

3. The samples that are suitable for using in base and sub-base course materials based on tests such as absorption, specific gravity, AIV, ACV, LAAV and slake durability index are: USC1, USC4, USC5, USC6, USC8, USC9, USC10, USC11, USC12, USC13, USC16, USC18 and USC19.

4. The coarse aggregates (clasts) from the Upper Siwalik Subgroup of the Chure Khola area generally meet the ASTM, BS and Nepal Standards and are acceptable for Unbound pavement.

7. It is recommended to skip some samples such as USC2, USC3 and USC17 due to their low strength and durability.

\section{REFRENECES}

ASTM, 1979. Standard test method of test for Triaxial Compressive Strength of undrained rock core specimen 
without pore pressure measurements. Annual book of ASTM Standard $632 \mathrm{p}$.

ASTM, 1994. Standard specification for transportation materials, and method of sampling, ASTM: C33. Washington DC.

ASTM, 2001. Standard Test Method for Slake Durability of Shales and Similar Weak Rocks: D4644-87 (Reapproved 1992). Annual Book of ASTM Standards, West Conshohocken, PA.

ASTM International, 2005. Standard test method for Soundness of Aggregates by use of sodium sulphate or magnesium sulphate. C88-05.ASTM International, 2005, Standard test method for Soundness of Aggregates by use of sodium sulphate or magnesium sulphate. C88-05, pp. $1-5$.

ASTM C 33, 2011. "Standard Specification for Concrete Aggregates.” ASTM International, West Conshohocken, PA, 2011, DOI: 10.1520/C0033-11.

ASTM C 127, 2011. "Standard Test Method for Density, Relative Density (Specific Gravity), and Absorption of Coarse Aggregate." ASTM International, West Conshohocken, PA, 2011, DOI: 10.1520/C0127-11.

ASTM C 131, 2006. "Standard Test Method for Resistance to Degradation of Small-Size coarse Aggregate by Abrasion and Impact in the Los Angeles Machine." ASTM International, West Conshohocken, PA, 2011, DOI: $10.1520 / \mathrm{C} 0131-06$.

ASTM C 136, 2011. "Standard Test Method for Sieve Analysis of Fine and Coarse Aggregates." ASTM International, West Conshohocken, PA, 2011, DOI: 10.1520/C0136- 11.

Bajarson, G., Petursson, P., and Erlingsson, S., 2000. Aggregate resistance to fragmentation, weathering and abrasion. Unbrand Aggregates in Road Construction (UNBAR) Reykjavik, 62p.

BS, 1989. Methods of determination of particle shape. BS 812 105.1, BSI, Flakiness index London., pp. 1-10.

BS, 1990. Testing aggregates Part 105. Methods for determination of particle shape. BS 812 105.2, Elongation index, London, pp 1-12

DOR, 2015. Standard Specification for Road and Bridge works, Reports of Ministry of Physical Planning and Works, pp. 1006-1200.

Gondal, M.N.I., N. Ashan, and A.Z. Javid, 2009. Engineering Properties of Potential Aggregate Resources from Eastern and Central Salt Sange, Pakistan, Geol. bull. Punjab Univ. 44 , pp. 97-103.

IS 10050,1981. "Method for determination of slake durability index of rocks", CED 48: Rock Mechanics, Indian Standards Institution,IS 1004.81.
IS 2386,1963. "Methods of Test for Aggregates for Concrete, Part I: Particle Size and Shape", [CED 2: Cement and Concrete], Bureau of Indian Standard, New Delhi 1100022386-02.

Khanal, S. and Tamrakar, N.K., 2009. Evaulation of quality of crushed-limestone and-siltstone for road aggregates. Bulletin of the Department of Geology, Tribhuvan University, Kathmandu, Nepal, Vol. 12, 2009, pp. 29-42.

Sah, R.B., Ulak, P.D., Gajurel, A.P., RImal, L.N., 1994. Lithistratigraphy of the Siwalik Sediment of AmlekhganjHetauda area, Sub Himalaya of Nepal, Himalayan Geology 15, pp. 37-48.

Shilstone,Sr., J. M. (1990). “Concrete Mixture Optimization.” Concrete International: Design and Construction, Vol. 12, No. 6, June, pp. 33-39.

Shrestha, S. and Tamrakar, N.K., 2013. Geotechnical properties of construction aggregates from the Trishuli Ganga River, Galchi area, Central Nepal. Bulletin of Department of Geology, Tribhuvan University, Kathmandu, Nepal v. 16, pp. 44-52.

Tamrakar, N.K., Yokota, S. and Shrestha S. D., 2002. Physical and Geomechanical Properties of the Siwalik Sandstones, Amlekhgunj-Suparitar Area, Central Nepal Himalaya, Jour. Nepal Geol. Soc., Vol. 26, pp. 59-71.

Tamrakar, N. K., Yokota, S. and Shrestha S. D., 2007. Relationship among Mechanical, Physical and Petrographic Properties of Siwalik Sandstones, Central Nepal Sub- Himalayas, Engineering Geology, Vol. 90, pp. 105-123. 